\title{
水利机电设备运行维修管理探讨
}

\author{
苏森 \\ 盐城市市区防洪工程管理处 \\ DOI:10.32629/hwr.v3i2.1928
}

[摘 要] 水利防洪在我国现行的灾害防控体系中有着十分重要的地位,对社会经济的安全生产做出了重要贡献。为了确保水 利防洪量达到预期目标,维持水利机电设备的正常运行,相关单位需要对其进行科学有效的维修与管理,将防洪工程的经济效 益与社会效益最大程度上发挥出来。因此, 本文深入讨论了水利机电设备维修与管理的实施路径以及需要注意的有关事项。

[关键词] 水利机电; 设备维修; 设备管理

随着我国现代化建设的不断发展, 城镇化建设的不断深 化, 城市经济发展规模以及民生项目建筑规模逐年扩大, 对 于生产生活环境的安全性也提出了越来越高的要求, 如何做 好水利电机设备的维修与管理工作已经成为相关单位十分 重要的研究课题之一。然而, 由于当前我国许多水利防洪单 位普遍存在管理思维陈旧、生产模式落后等方面的问题, 仍 然需要在水利机电设备维修与管理工作方面进行深入的研 究与探索。

\section{1 水利机电设备维修与管理工作的意义}

对于防洪部门来说, 做好水利机电设备的维修与管理工 作对于生产组织有着十分重要的促进作用, 同时也是提升生 产组织有效性、做好成本控制工作的关键环节。在机电设备 投入使用的过程中, 若没有及时发现相关的异常现象, 很有 可能造成更大规模的设备损坏。设备在出现故障的情况下一 般会自动停止运行, 可能会对防洪部门整体的生产效率造成 负面影响, 进而造成相应的经济损失。随着我国水利防洪技 术的不断发展、经济建设对安全环境的依赖度越来越高, 防 洪工程也迎来了更大的挑战, 相关单位也开始强化了对于维 修与管理工作的重视力度, 尤其是在各种新型设备与现代化 技术不断投入使用的情况下, 许多防洪部门已经逐渐建立起 了新型的维护与检修体系。通过科学有效的维护与检修工作, 能够使防洪部门的日常管理日益趋向完备化、精细化, 进而 实现管理效率和资源分配效率的进一步提升。对于防洪部门 来说, 针对水利机电设备所进行维护与管理已经成为促进产 业升级、转变经营方式的战略要素之一, 提升各项资源之间 的协调性。由此可知, 水利机电设备的维护与管理工作, 能够 将各种可用资源、人力组织、生产计划以及管理体系整合在 一起, 既能够实现设备整体运行性能的提升, 同时也能够促 进防洪工作的进一步发展, 为社会经济的平稳发展创造良好 的外部环境。

\section{2 防洪部门机电设备维护检修管理的方法分类}

针对水利机电设备所进行的维修与管理工作, 可以采用 各种不同的实施路径与技术手段, 分别应对各种不同的运维 侧重点。在维修工作方面, 具体有以下四种维修类型, 即状态 化维护、优化性检测维修、定期检测维修、被动维修检修。
其中被动维修检修指的是在水利机电设备出现故障的情况 下实施事后维修, 采用该维修模式代表了设备已经出现故障 并且停运, 即已经造成了既定的不良影响。对于防洪部门这 样具有特殊地位的重要单位, 出现被动维修检修的概率相对 较低, 防洪部门自身也会综合运用各种手段避免采用该维护 模式。定期检测维修指的是根据防洪电机设备的使用周期和 基本特性, 在特殊的时间范围内、以固定的频率进行维修, 防止因突发故障而对整个防洪部门的正常运行造成影响, 这 也是一种十分常见的水利机电设备运维模式。设备优化性检 修指的是专业技术人员在深入分析设备基本特性和性能特 点的情况下, 重点处理极易造成故障的有关因素, 采用更加 先进的技术手段来改进设备，降低设备出现故障的频率。以 主动维修替代以往的被动维修, 这有助于实现防洪部门整体 运行设备的提升。状态化维护指的是持续采集与水利机电设 备运行状态相关的数据信息, 根据常规运行参数对异常参数 与现象进行判断, 进而起到防患于未燃的效果。该维修模式 能够为维修工作提供数据支持。

\section{3 防洪部门机电设备维护检修管理措施建议}

\section{1 建立健全维护检修制度}

针对水利机电设备所进行的管理工作, 需要有一个切实 可行的制度提供指导与支持, 促进相关管理工作的有序落实 并充分发挥作用, 这也是防洪部门维持正常运行的必要条 件。另外, 防洪部门自身也要对各种设备的差异性和特殊性 有一个全面的了解, 深入分析防洪部门的实际运行需求, 对 水利机电设备的维修机制进行不断的优化与调整, 进而形成 一套更加完善、更具可行性的维护检修制度。相关维修人员 也要对各种设备的运行状态进行持续性的跟踪观察, 在修改 或调整检修制度的过程中, 应照顾到对运行条件有特殊需求 的设备, 确保所有设备的运转都能够保持相对稳定的状态。 在实施维护与检修工作的过程中, 维修人员要深入掌握各种 水利机电设备的运行状态, 基于设备生产商所提供的说明书 来制定维修制度, 不再单纯依靠以往的维修工作经验。另外, 维修人员也要对维修时间进行合理化的安排, 处理好水利机 电正常运转与有限维修资源之间的矛盾, 最终实现整个防洪 部门运行效率的提升。 


\section{2 选择防洪部门委托管理模式}

新形势下的防洪管理工作可考虑采用委托管理模式或 自运行管理模式。其中自运行管理模式指的是, 针对水利机 电设备进行的管理与维修工作均由防洪部门内部人员负责 实施; 委托管理模式指的是防洪部门将针对水利机电设备所 进行的维修工作外包给第三方负责实施。委托管理模式包括 维护检修委托管理、运维委托管理以及全部委托运营管理三 种模式。由于水利机电维修工作对专业性有着较强的要求并 且实施起来十分繁琐, 对于人力资源的需求也相对较大, 尤 其是在国有企业改革的大背景下, 委托管理模式防洪部门企 业未来主要的发展趋势。其中, 全部委托运营指的是防洪部 门将经营职责与生产运行现职全部外包给第三方, 根据合同 向第三方支持运维与经营费用。运维委托管理指的是单纯将 生产运行部分外包出去, 保留经营职责, 防洪部门负责向第 三方支持运行管理报酬, 自身负责内部的管理与控制。维护 检修委托管理指的是, 运行管理与经营管理均由防洪部门负 责, 单纯外包水利机电设备的检修工作。不同规模、不同运 行特点的防洪部门应依照行业动作特点和企业自身的特色, 有针对性地对委托管理模式进行选择。同时也要篮选出具有 专业资质、技术能够成熟的管理企业, 维持防洪部门的正常 动作与健康发展。

3.3 降低防洪部门委托管理风险

委托方风险可以具体划分为政策风险、自然风险、经济 风险以及人为风险等。其中人为风险又可以划分为不可预见 事件风险与人员管理水平风险等; 自然风险可以划分为自然 小灾害、恶劣现场环境与恶劣气候条件等。被委托方风险可 以划分为、发电设备设施性能风险、责任风险、人员管理水 平等。对于防洪部门来说, 管理风险一般集中在技术人员道 德品质、技术水平以及管理水平等; 责任风险一般集中于替 代责任风险、委托费用风险等。也就是说, 防洪部门无论选 择了哪一种委托管理模式, 均要承担相应的风险。这就需要 防洪部门有关负责人对各种委托机制的特点有一个全面且 深入的了解, 正确判断并评估各类风险的特点, 最大程度上 发挥出防洪部门的经济效益。

\section{4 加强防洪部门运行设备维护管理}

为了维护水利机电设备的正常动作, 防洪部门在做好日 常维修工作的同时, 也要做好相关的管理工作, 以高水平的 管理来降低维修方面的压力。首先, 防洪部门应专门建立起 一套切实可行的管理机制, 明确第一名管理人员的责任与义 务, 根据相关的维修数据来明确管理工作的侧重点。管理人 员自身也要不断加强学习, 改善自身的知识结构, 转变传统 的管理思维, 升级管理技术。大胆引入计算机设备与专业的 管理软件, 以数字化、信息化技术实现管理工作的实时化、 全面化。管理人员与维修人员也要加强沟通与合作, 以管理 促维修, 以维修辅助管理, 充分实现二者之间的技术共享与 数据资源共享, 确保防洪部门通过在合理成本下实现稳定的 运行。

\section{5 结束语}

机电设备的维护检修管理对防洪部门的生产计划实施、 经济效益等有一定的影响, 必须放到各级设备管理部门的重 要工作任务中去。文章从防洪部门机电设备维护检修管理的 必要性、方法分类以及解决措施等方面对机电设备的管理模 式和管理风险等进行了简单的探讨, 希望能为相关从业人员 提供一些有益的参考和帮助。

\section{[参考文献]}

[1]任正福.对防洪部门机电设备检修运维管理的思考 [J].中国设备工程,2017,(23):96-97.

[2]庄伟栋,邱晓侨.水利工程葲站机电设备故障诊断方 法分析[J].江苏科技信息,2018,35(31):45-47.

[3]吕淑峰,黎华.水力机电设备常见运行异常问题解析 $[J]$.科技创新与应用,2013,(14):127.

[4]李正军,张建武.浅谈水利机电设备的维修及管理 [J]. 技术与市场,2014,21(12):212。

[5]李奎.试论我国水利洜站机电设备运行管理中的问题 及措施[J].科技经济市场,2017,(04):182-184.

[6]王卫军.浅析机电设备维修与管理存在的问题及对策 [J].四川水泥,2016,(04):120。 